\title{
BUILDING INFORMATION MODELLING IN ARCHITECTURAL EDUCATION: CONTRIBUTION OF BIM IN DESIGN PROCESS
}

\author{
Hülya SOYDAŞ ÇAKIR \\ Fenerbahçe University, Turkey \\ hulya.soydas@fbu.edu.tr \\ https://orcid.org/0000-0002-4631-510X \\ Türkan UZUN \\ Maltepe University, Turkey \\ turkanuzun@maltepe.edu.tr \\ https://orcid.org/0000-0002-3306-0101
}

\begin{abstract}
The fact that the practice of BIM has turned into a global trend; has also made BIM a significant constituent in architectural education. Computer aided design courses have long been integrated into the curriculum because of the progress of design in digital platforms and the benefits it compromises. Schools of Design exploit BIM along with several computer aided design software. This study compares the fundamentals contributing to design ability of architecture undergraduate students at two universities in Turkey practising BIM-based courses which intend to help students recognize the rationale and the benefits of BIM and to raise awareness of using BIM-based software. The results of the practices by the end of week eight and models of final submissions at the end of the semester were both evaluated in relation to student work reports. The evaluation includes how BIM-based software in curriculum contribute to architectural project design.
\end{abstract}

Keywords: BIM, Building Information Modelling, Architecture, Design Process, Architectural Education

\section{MIMMARLIK EĞITTIMINDE BIM: BIM’İN TASARIM SÜRECINE KATKISI}

\section{öz}

BIM kullanımının dünyada hızla yaygınlaşması, mimarlık eğitiminde de gündeme gelmesinin önemini artırmıştır. Tasarımın sayısal alanda gelişimi ve tüm avantajları dikkate alınarak, bilgisayar destekli tasarım dersleri uzun zaman önce mimarlık eğitimi müfredatına dahil edilmeye başlanmıştır. Tasarım okullarında farklı bilgisayar destekli tasarım yazılımları yanısıra BIM yazılımlarından yararlanılmaktadır. Bu çalışmada Türkiye'de iki farklı üniversitenin mimarlık lisans eğitim müfredatında yer alan BIM tabanlı yazılımın kullanıldığ 1 derslerde mimarlık öğrencilerinin tasarım yeteneklerinin gelişimine yönelik unsurlar araştırılmıștır. Bu dersler ile öğrencilerin BIM'in amaç ve avantajlarını kavramaları, BIM tabanlı yazılımların kullanım bilincinin yükseltilmesi amaçlanmaktadır. Dersin sekizinci haftasında gerçekleştirilen uygulama çalışmalarının sonuçları ve dönem sonu elde edilen final teslimlerinden oluşan modeller, öğrenci çalışma raporlarına göre değerlendirilmiştir. Değerlendirmede BIM tabanlı yazılımların ders içeriğinde kullanılmasının mimari proje tasarımına katkısı irdelenmiştir.

Anahtar Kelimeler: BIM, Yapı Bilgi Modelleme, Mimarlık, Tasarım Süreci, Mimarlık Eğitimi 


\section{INTRODUCTION}

Technological developments in the building industry and architecture have given way to the creation of new working methods in digital design platforms. With the globally growing urban populations, the demand for housing has increased which has necessitated the management of interdisciplinary relations between project design management, facility management and organisation of building sites. In order to be able to administer these different disciplines, new software had to be developed. In the last 20 years, BIM (Building Information Modelling) software and working method has been commonly used for this purpose. BIM separates from other modelling software not only because it is a 3D modelling tool but as it also is a medium for building design management, it creates a platform to work with other disciplines, it provides integrated project environment (Eastman, Teicholz, Sacks, \& Liston, 2008), it provides the opportunity to simulate building structure materials by creating virtual modelling environment and it emerges as an innovative way to design and manage projects (Azhar, 2011).

This article analyses the instructional content and its practices in sample curricula to contribute to the effective use of BIM working method in architectural education. Research is being carried out to evaluate the contributions BIM practices provide for the users and their effectiveness in terms improving design abilities.

\section{BIM SOFTWARE}

BIM is a family based software that contains parametric information which especially makes it more privileged compared to other methods. Surface design, conceptual design, detail design, renovation or demolishing of the object can all be managed through BIM interface. BIM based project gives extra advantage to the contractor in terms of material choice, visualization of material in the model, providing images during presentation stage, the availability of rendering, converting the design into animated form, providing countless sections and elevations, tender pricing for construction phase, site controlling, doing all the measurements and providing quantitative data. Eastman et al. (2008) define BIM as a suitable method for construction activity of human rather than being a means of tool that provides the opportunity to work by perceiving the design formally; underline that BIM is an innovative approach in design and project construction and management.

BIM is multitasking software providing information on the materials, generating sheets, managing sections, providing 3D rendering support, analysing lighting and thermal performance, analysing process performance and including analysis of interdisciplinary intersections.

\section{Benefits of BIM software}

BIM software does not only facilitate 3D modelling but also gives support to design, does cost analysis, provides coordination of project management and helps forming production details. As visualization is one of the main features of BIM (Wu, Chen, Cai, Lu, Wang, \& Yu, 2019), its usage is very attractive in terms of analyzing construction time, labor and cost beside providing $3 \mathrm{D}$ modelling. 
BIM software speeds up the drawing process as it automates project documentation and provides simultaneous design opportunity. Reflection of all changes on all of the documents at the same time facilitates workflow and minimizes errors. The time saved during the process reduces the labor cost of project design and drawing procedure. In any later stage of the project, the design options tab allows to form alternatives of the design. BIM can be used as a multi-disciplinary collaboration platform (Singh, Gu, \& Wang, 2011).

Technologies help designers to express their creativity and to assess their ideas and solutions (Bonnardel \& Zenasni, 2010). Analysis of other disciplines such as mechanical, electrical and structural can be done simultaneously with BIM model during the design process providing more accurate and high quality design and efficiency. The software stores all data and provides access to the project data for contractor and mechanical, electrical, structural groups in the later stages of the project. By facilitating design review and achieving functional performance, BIM supports better outcomes in design (Gurevic, Sacks, \& Shrestha, 2017). The benefits of the BIM process and database would be useful throughout the life cycle of a building not only from planning to construction (Epstein, 2012). Creating awareness about the contribution of BIM applications in project process facilitates BIM adoption in the industry ( $\mathrm{Gu} \&$ London, 2010).

\section{BIM and architectural design education cross section}

Many architecture departments around the world adopt different schools of thought and computer aided studio experiences in order to provide an efficient architectural education due to its application based nature. Students prefer computer aided design courses with various content in order to develop their design abilities in their education process (Çakır S., 2016). The conceptual design modelling feature of BIM brings it to the attention of architecture and design graduate degree programs along with innovative approaches in architectural education curricula. BIM courses to be included in the curriculum in the early stages of education will enable them to allocate more time to design and presentation for design studios (Ofluoğlu, 2017). As the results of a research based on the experiences of construction companies; one of the often mentioned barriers for BIM working method was the lack of qualified BIM software users, therefore there is need for BIM competent graduates (Ku \& Taiebat, 2011). Integrating BIM into curriculum as a response to demands in industry (Joannides, Olbina, \& Issa, 2012) will enable students to experience BIM tools and become ready for profession (Farnsworth, Beveridge, Miller, \& Christofferson, 2015). BIM courses need to take place not only in undergraduate and graduate programs, but also in professional life such as education programs, in-house training meetings and workshops (Gokuc \& Arditi, 2017).

There were various researches aiming to investigate benefits and outcomes of BIM courses in architectural education (e.g. Abdelhameed, 2018; Mandhar \& Mandhar, 2013; Becerik-Gerber, Gerber, \& Ku, 2011; Barison \& Santos, 2010). In a study examining BIM awareness of architecture students, the demand for BIM education was found to be high. While BIM awareness was higher in the upper classes, it was emphasized that a balanced BIM curriculum was required for the lower and upper classes (Ahn \& Kim, 2016). According to a research covering sample schools in three different countries, students perceive usefulness of BIM in early project stages and design-related studies (Jin, Zou, Li, Piroozfar \& Painting, 2018).

As design is an activity with the application of scientific and technological knowledge, design processes are complex and there are no formulas to bring together form, function, context and technologies (Kowaltowski, Bianchi, \& Teixeira de Paiva, 2010). Digital platforms are not the only means to develop design ability and it actually depends on individual capabilities and the data in the memory related to design. There are certain directories in digital databases and human memory. As directories are different in each individual's memory, a group of students working under equal conditions will all design different products. A studio study has been carried out to observe these differences where students were given a draft in ".dwg" format with outlined borders and defined function. When students were asked to submit a unique model using given ".dwg" draft with any 3D modelling software, the result products were all in different forms (Uzun, 2011). Since the project will be exposed from different "memory" data, the results will never be identical. Mathews (2013), pointed out the collaborative properties of BIM applications during a design studio research examining the learners' experiences. In a study investigating the efficiency of early stage design studies, it was concluded that BIM tools provide the opportunity to test existing designs and develop them (Çavuşoğlu, 2015). In another study conducted in design studios, a design framework was developed 
using BIM in various design processes, including architectural programming, conceptual design, parametric design, digital production and interaction design, and it was revealed that BIM can be used as an integrated tool for design (Wu \& Jeng, 2012). As architecture is not just the application of knowledge, techniques and skills, BIM is considered beyond a simple tool (Ambrose, 2012). The ability to process and evaluate all kinds of project data at the beginning of the architectural design significantly affects the success of design. In this context students can actively apply and visualize data in their design projects by using BIM.

BIM allows an alternative design process parallel to traditional creativity and construction processes with parametric design. Parametric thinking encourages students to bridge between technical knowledge and creativity. BIM also redefines the production way of design ideas by combining creativity with design and technological innovations (Zarzycki, 2012). In design studios, projects can be prepared to encourage students to explore many design possibilities. The goal is to develop a set of ways to explore a design problem rather than finding one way to solve it (Ambrose \& Fry, 2012). In a study by Souza et al. (2019) conducted with undergraduate students, it is verified that with BIM working method, an environment is created where creative reasoning is encouraged and the graphical representation of complex forms designed in a parametric digital environment is facilitated. The contributions and advantages of BIM working method in architectural education continue to guide design research.

\section{CASE STUDY}

\section{Aim, scope and method}

The aim of this study is to measure the effectiveness of BIM-based software regarding design abilities of architecture students. Selective courses using BIM-based software in the undergraduate architectural education curriculum were examined within the scope of this research. 63 architecture students from two private foundation universities in their 2nd, 3rd and 4th year have been involved in the research. The study was based on 4 undergraduate courses given in three academic semesters; MIM417 3D Modelling in Computer-based Design, MIM332 Advanced Presentation Techniques (A and B branches) and MIM332 Advanced Presentation Techniques. These courses have been observed for 14 weeks and the findings regarding learning attainments and awareness of software use have been analysed. As for the research method, a three period approach has been used and these three periods encompass two annual projects, one final project given at the end of the semester. In addition, structural and design skills acquired during the final week of the BIM course were requested to be submitted in Design Studio projects at the end of the course by correlated with Design Studios.

In the first eight weeks of courses, basic commands of BIM-based Revit program were taught through practice. The results of the 1 st and 8th week of the first period were achieved through a three-hour quiz in class in the 8th week. Students were also asked to report their weekly work hours, methods and commands they used. The second period has covered the time between week 8 and week 14. During this period, topics like light, material, layout and render were covered. At the end of the second period, they were asked to develop and submit a project again. In the third period, the final project was assessed and evaluated. This period covers the evaluation of the work reports. In period submissions, the students were required to model the given plan by a ".dwg" file from base to roof in defined time periods. Due to the limited number of lessons per week, it was decided to give an existing prototype plan in order to allocate more time for modelling and design decisions. The students were told that the modelling was enabling modification and that they were allowed to improve the given draft project by making additions depending on their design. In both periods all data collected from the students were evaluated together with the reports in the context of process/result. The research has been finalised by interpreting the models produced by students from different achievement levels and the cumulative data.

The students received a total of 42 hours of applied training in the form of 3-hour-a-week in 14 weeks. The students were allowed to choose this course from the 4th semester of their degree program. The methodology of teaching entailed explaining the basic commands, observing, comprehension and applying. Reports have been collected to examine the amount of work the students did outside of class and it was observed that students were revising depending on their need.

\section{First period of case study}


In the instructions of the first period, an 80 square meter base plan has been used (Figure 1). The students were asked to create a 3D model using all components of walls, floors, doors, windows, stairs, roof and all the relevant materials for these components. Furnishing and camera placement are given as additional work after the model is completed.

Basic commands in the interface of Revit Architecture were delivered to the students and their practices were completed by week eight. In the 8th week, the students were given a three-hour-quiz where they were required to model the given project from base to roof. They were also given the flexibility to use advanced commands if they managed to add furniture and other materials.

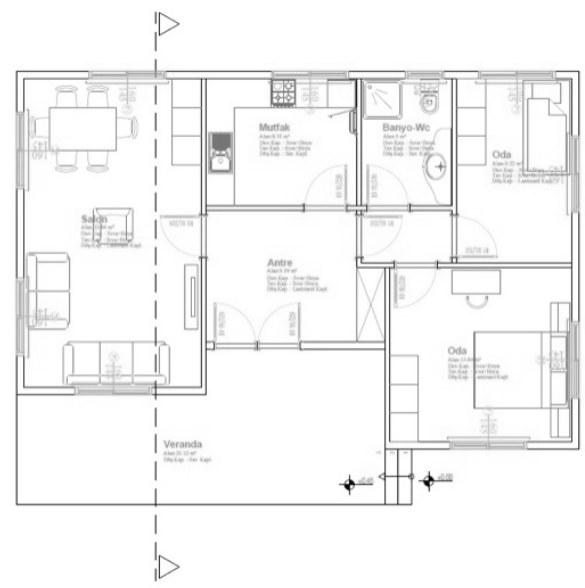

Figure 1. Draft of given .dwg plan

Those students who did not miss a single class were asked to improve the plan by using simple commands and use additional design components to take the project one step further. These additions could be elements changing perspectives on the building plans and facades such as balconies, porches, oriel windows or roofs. With these additions, it was aimed to observe how capable the students were in managing BIM in simultaneously designing an 80 square meter house of one living room, 2 bedrooms, a hall, a bathroom and a kitchen given as draft ".dwg" format in the first period. Students were asked to try different parameters for window and door openings on the facade to develop their 3D design abilities. Students were left free with their design decisions such as vertical/horizontal measurements, curtain wall divisions, "full/empty" and "wall/glass" relations, transparency, permeability, height, landscape and flexibility in size.

In this process where the aim was to test the ability of modelling from base to roof, it was observed that some students (e.g. Student 1, Student 2) could not complete the roof and were not able to make any additions other than boundary of given base drawing (Table 1). When work reports were compared, it was noted that those students did two hours of extra work outside of class (Table 2). 
Table 1. Students who could not make additional design outside the drawing boundaries in the first period

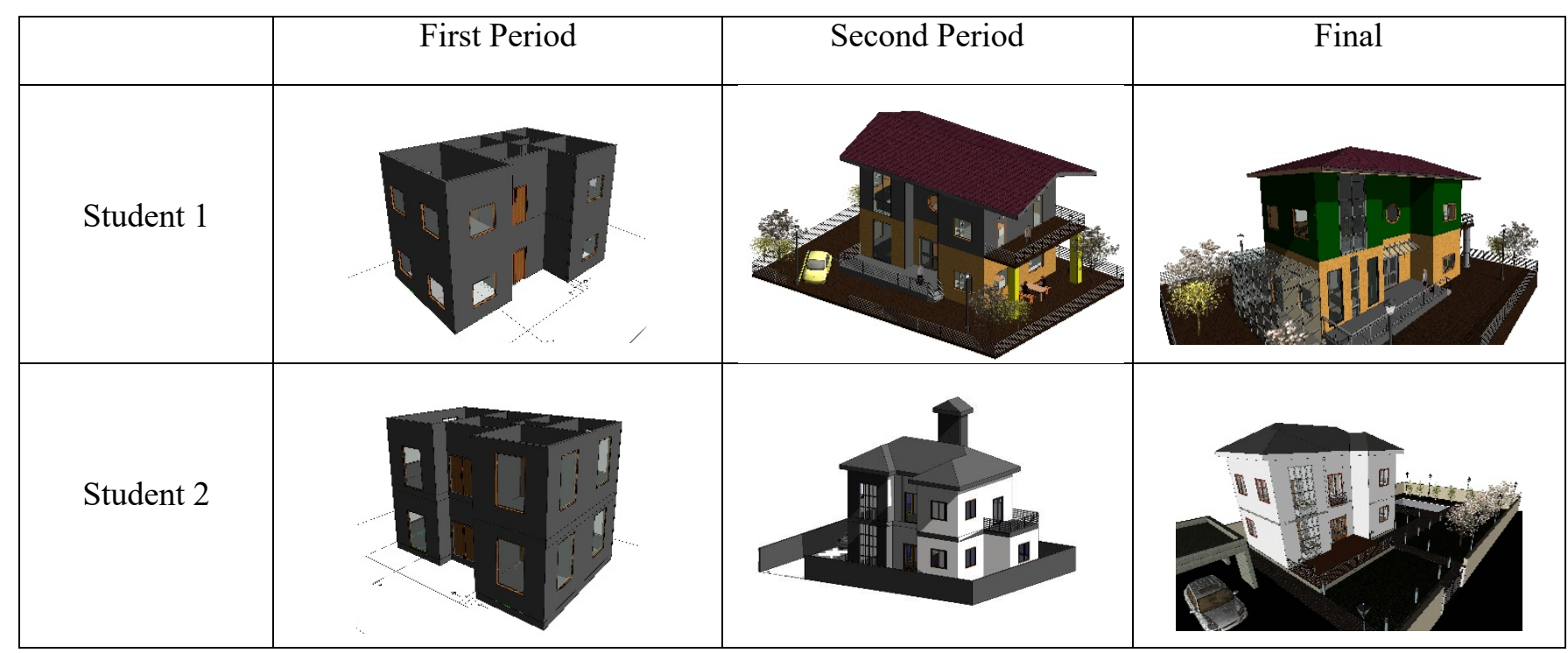

In addition, Student 3, Student 4, Student 6, Student 7, Student 8, Student 9, Student 10, Student 11, Student 14, Student 15 and Student 19 stated that they worked two hours out of class, Student 17 and Student 20 said they worked one hour each (Table 2).

Table 2. Sample Work Hours

\begin{tabular}{|c|c|c|c|c|c|}
\hline \multirow[b]{2}{*}{ PARTICIPANT } & \multicolumn{2}{|c|}{ WORK HOURS } & \multirow[b]{2}{*}{ PARTICIPANT } & \multicolumn{2}{|c|}{ WORK HOURS } \\
\hline & First period & Second period & & First period & Second period \\
\hline Student 1 & 2 & 4 & Student 11 & 2 & 2 \\
\hline Student 2 & 2 & 5 & Student 12 & 7 & 15 \\
\hline Student 3 & 2 & 2 & Student 13 & 4 & 4 \\
\hline Student 4 & 2 & 4 & Student 14 & 2 & 2 \\
\hline Student 5 & 4 & 8 & Student 15 & 2 & 4 \\
\hline Student 6 & 2 & 2 & Student 16 & 10 & 10 \\
\hline Student 7 & 2 & 4 & Student 17 & 1 & 4 \\
\hline Student 8 & 2 & 2 & Student 18 & 4 & 5 \\
\hline Student 9 & 2 & 2 & Student 19 & 2 & 2 \\
\hline Student 10 & 2 & 2 & Student 20 & 1 & 2 \\
\hline
\end{tabular}

Student 5, Student 12, Student 13 who were able to raise the project above the expected level, seem to have studied for at least four extra hours (Table 3). 
Table 3. Students with projects above the expected level

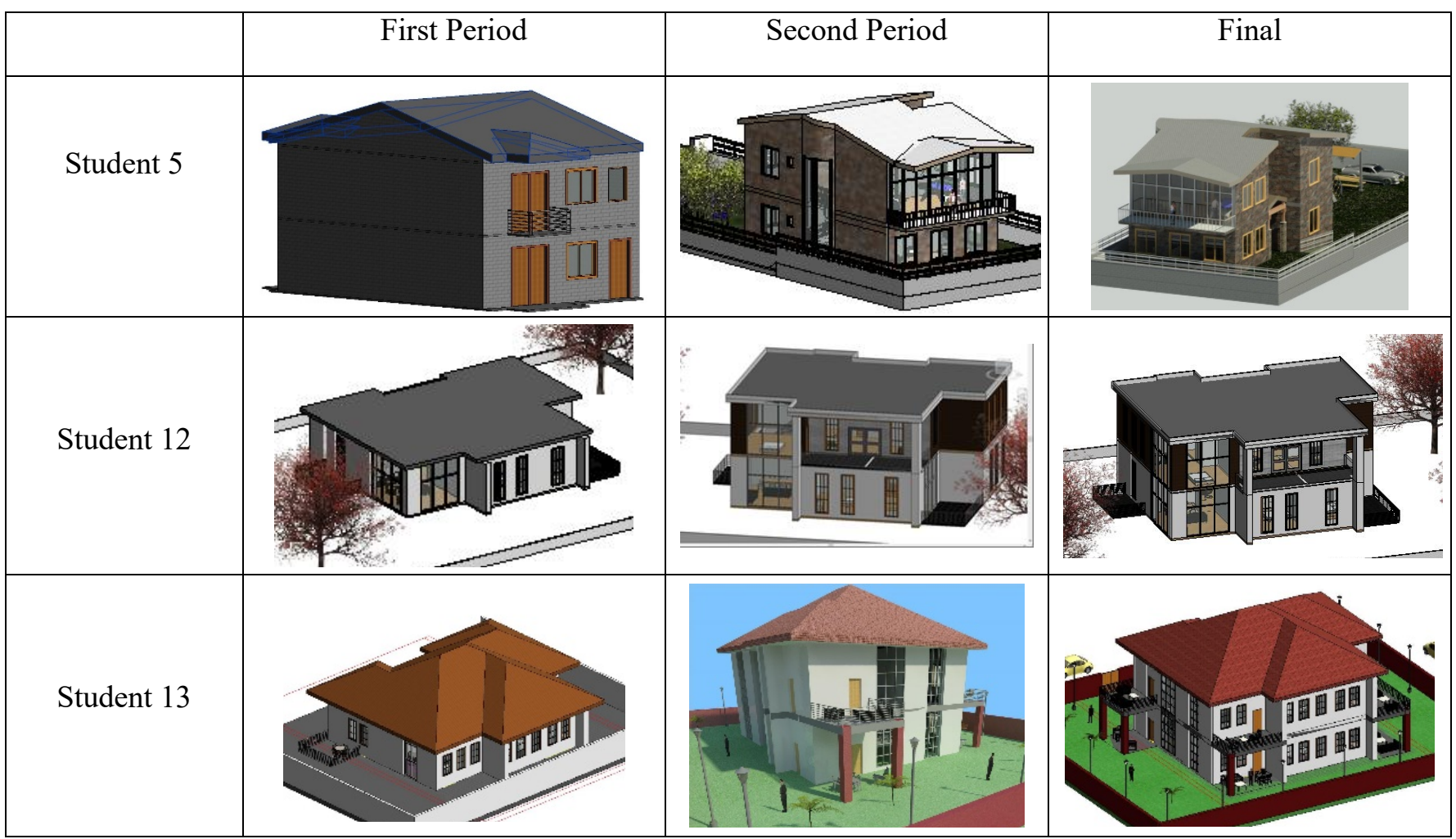

For the other samples, after evaluating Table 2 in which working hours outside of class are given and submitted project levels, two conclusions were reached. The first result is that, students who are assumed to have little knowledge of BIM need to do extra work. The second one is that, students who did extra work outside of class were capable of fulfilling the requirements by installing the roof, walls and the staircase appropriately, could make simple additions and could enlarge space and determine the boundaries of garden and landscape. The evaluation criteria such as the placement of doors, walls, columns, windows and other components that are sought in architectural and structural integrity, quantitative and qualitative use of curtain wall design skills in the architectural project, the assignment of materials, ability in environmental design are the reasons for some projects to come to the fore.

It was noted that Student 16 and Student 18 who had worked with a BIM-based software before electing the course, have proven to gain acceleration while modelling in the first period. For instance, they managed to work on structural systems, process landscape/environmental data and tried to realize or at least apply abilities to the model in the first period which were actually required in the second period. It has been observed that they can carry these competencies to the second and final period projects (Table 4). 
Table 4. Students worked with a BIM-based software before electing the course

\begin{tabular}{|l|c|c|c|}
\hline & First Period & Second Period & Final \\
\hline Student 16 & & & \\
Student 18 & & &
\end{tabular}

\section{Second period studies}

In the second period, in addition to the expectations of the first period, students were given the opportunity to modify the plan design regarding material selection, management of structural systems, presentation, legend, processing pavements, street lights and other environmental components, arranging landscape and they were observed for their abilities.

Students were allowed to use a different villa plan in the second period (Figure 2). Student 12 and Student 18 were able to proceed with the model in a faster manner, they were able to complete all the instructions at the end of the period and they improved the design of the villa by adding window, balcony, French balcony, railing and they were able to furnish with appropriate material and use elements of landscape design and garden furniture (Table 3, Table 4).
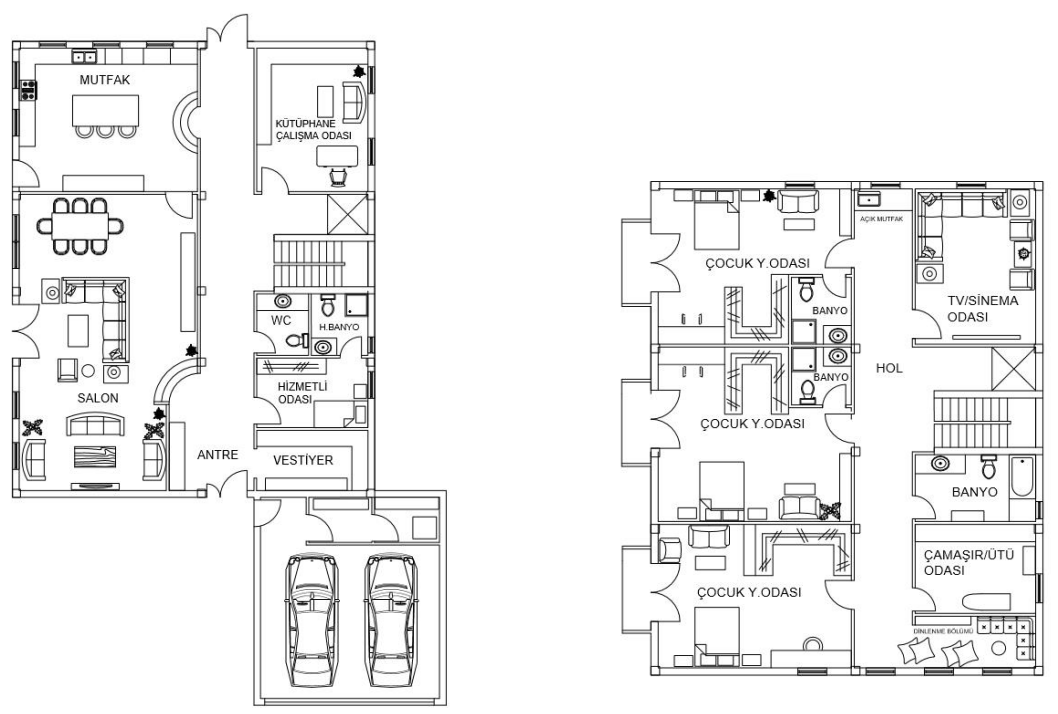

Figure 2. Second period ground floor and first floor plans

Student 1 who had not been able to complete the roof of the model in the first period, increased the building components completed in the second period. While the same student reported 2 hours of extra work outside of class per week, in the proceeding weeks it was reported that the student doubled the 
amount of extra work (Table 2). Doing extra work outside of class reflected itself in the improvement of the modelling performance.

Among the contributions of second period instructions to visualisation are to be able to view the entire 3D model, to view all types of spaces in the building separately and to create animation tour, to view from different camera angles, to render and to design in BIM environment. Study groups of 2nd and 4th year students reported to have completed the model in one day and four hours. All the BIM users in the 2nd period admitted to have improved compared to the 1st period and by improvement they meant applying beyond the given commands like installing stairs and rails, using floor component, forming galleries, installing cameras, rendering, designing the garden and landscape, working on the roads and modelling the topography.

It was observed that students who doubled their working hours after the first period as Student 4, Student 7 and Student 15, improved their BIM skills in final projects, even if they could not reflect it in the second period. Student 4 who was using the software for the first time managed to simply model the plan at the end of the first period and at the end of the second period was able to improve the plan and model with individual effort by the help of additional commands and extra work outside of class. The student improved the modelling by adding components like material, furniture, plant, vehicle and human. The student also seemed to be quite confident with glass facade and elements of railing (Table 5).

Table 5. Students who increased their working hours in the second period

\begin{tabular}{|l|c|c|c|}
\hline First Period & Second Period & Final \\
\hline Student 4 & & & \\
\hline
\end{tabular}

Although they were taking the course for the first time, Student 4, Student 12 and Student 18 who were doing extra work outside of class, were observed to go beyond average expectation in the 2 nd period by assigning material, using column and roof, installing cameras and completing the model. The study of Student 16 who attended the course with the preliminary information, were noted to stand out among the class samples and went beyond the expectations by making additions (Table 4). 


\section{End of period evaluations}

When the work reports and levels of models were analysed, it could be concluded that, there were both a group of students who had not worked with BIM software and another group who could not make enough progress as they could not adapt to the object-based parametric modelling working principle of the software although they had tried to learn it in the past. This second group with some base were observed to have built up on their knowledge in the first period and have accelerated in the second period by increasing their work hours. The same group who were capable of understanding the basic commands were reported to have exceeded the expectations in the quiz with the instruction "you are expected to make design additions by improving the model" in the second period at the end of 14th week and they were able to work with BIM from the very beginning and submit their projects.

It was observed that Student 3 with a low level of progress in the first and second periods, increased the working hours and made progress in the final. This student was able to use advanced BIM skills such as landscaping, roads, lighting and materials. Students modelling walls, roofs, doors, windows at a simple level without furniture and without materials in the first period, used model developing commands such as material, furniture, railing, landscape, flooring in the second period. The same students in the final period used roof skylights (Student 6), different roof levels (Student 8) and curtain wall (Student 9) (Table 6).

Table 6. Students who progressed after the first and second periods

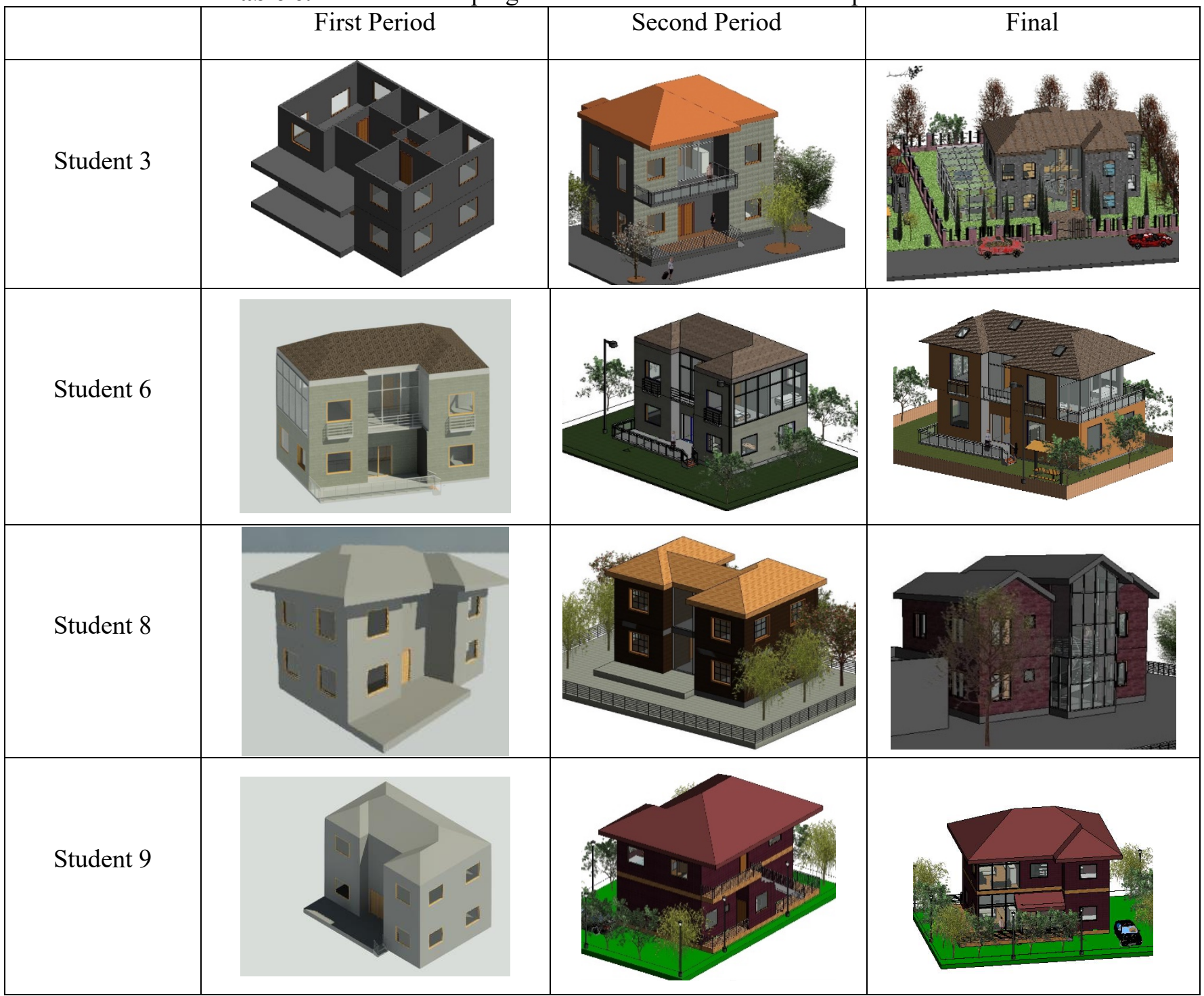


Some students (e.g. Student 10, Student 11, Student 14) could not make much structural progress between the first and the second period, however, they improved in interior furnishing and applying commands. These students could not be active in expanding the design boundaries. They made simple practices on roof forms, curtain walls, balconies, railings and windows (Table 7).

Table 7. Students who progressed in interior design instead of structure

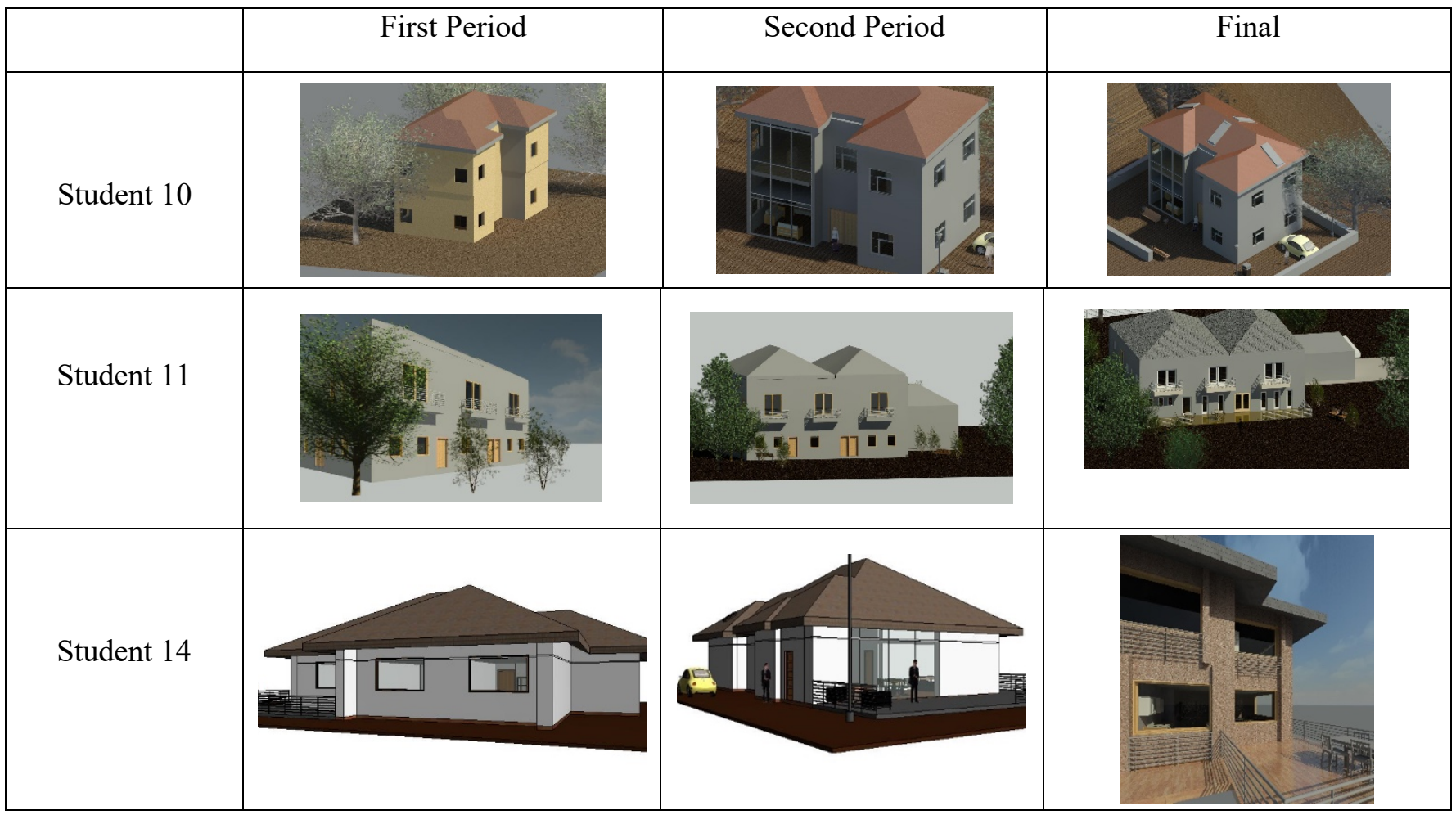

Student 12, Student 13, Student 14 started the first period with single-storey models, where most of the students created two-storey models (Table 3, Table 7). It was observed that these students lagged behind other students in process and instruction management. However, they progressed and caught up with others in the second and final periods by using BIM structural components. It was observed that Student 16, Student 17, Student 18, Student 19 and Student 20 performed BIM modelling at a higher level than the average level of the class since the first period. It was concluded that participation in the course, applying course instructions completely, providing additional designs, conducting above average course studies, using other 2D and 3D software and acquired structural knowledge were the determining criteria for the projects that stand out in this study. These results were determined from classwork of students throughout the semester and working report data.

A group of students who could not complete the roofing and the basic commands in the first period, were able to add of curtain wall, column and elements of lighting, however they failed to add any building design component. On the other hand, it was determined that Student 12 who stated the increase in working hours from 7 hours to 15 hours, could not improve the design of given draft project in the final submission, could not make any design addition; therefore, this student was an exceptional participant when the improvement of design skills was compared with the increase in reported working hours.

Participants who completed the model in the first period using basic commands in the instructions seemed to advance the models in the second and final periods (e.g. Student 7, Student 16) (Table 4, Table 5). Those participants who carried the design forward by making the applications above the expectations in the first and second periods, made significant contributions to the products in the submission of third period (e.g. Student 17, Student 19, Student 20) (Table 8). 
Table 8. Students who are advanced in the first period, second period and final projects

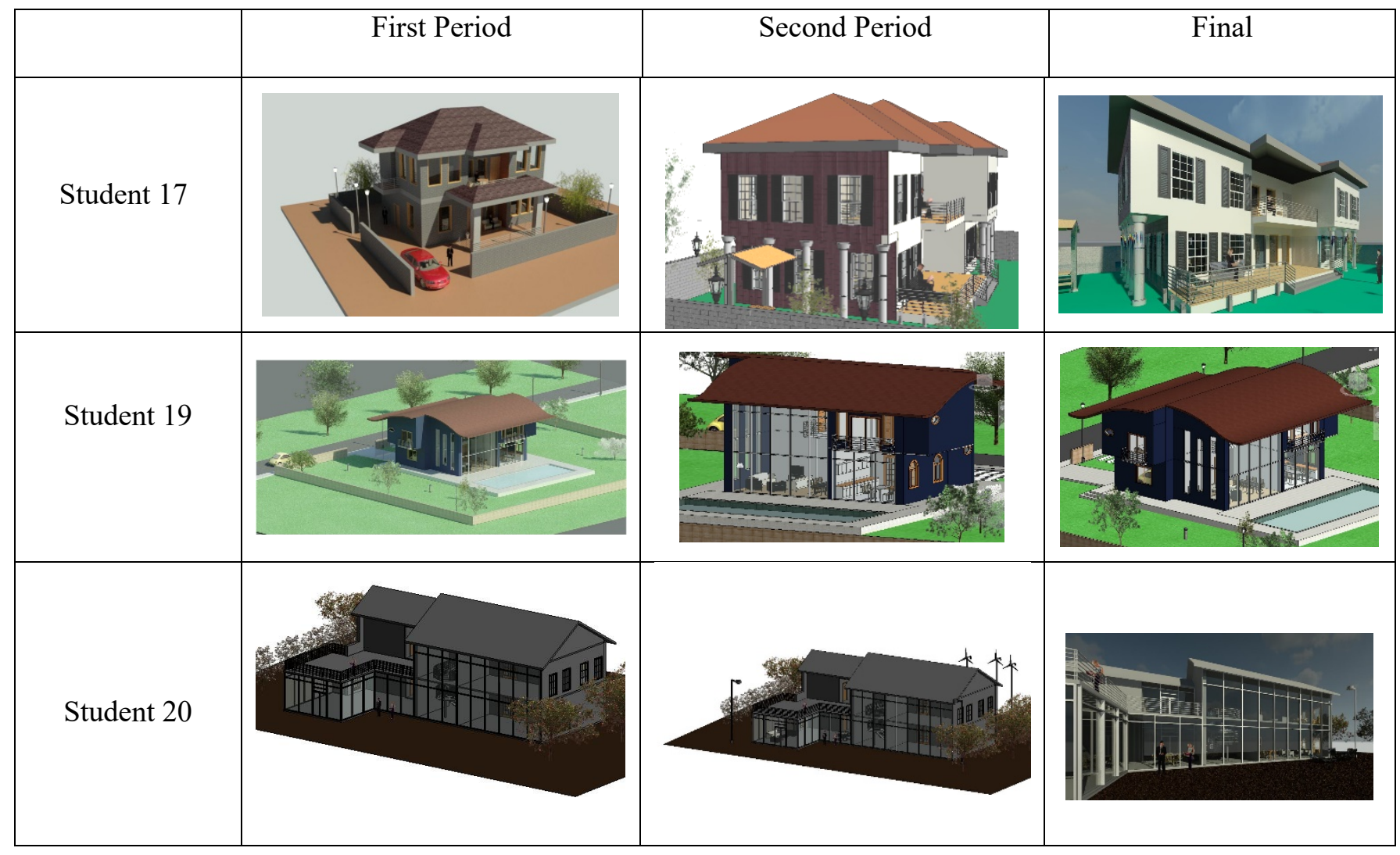

It was concluded that students gained high and average level of proficiency in basic commands and less/none or adequate level of proficiency in numerical commands like dimension, area calculation (Table 9).

Table 9. Tools and levels of proficiency students gained at the end of the semester

\begin{tabular}{|l|l|l|l|}
\hline \multirow{2}{*}{ LEVEL } & \multicolumn{3}{|c|}{ TOOLS } \\
\cline { 2 - 4 } UPPER & BASIC & STRUCTURAL & VISUALISATION \\
\hline INTERMEDIATE & $\begin{array}{l}\text { Using current library } \\
\text { components } \\
\text { Separating interior space } \\
\text { Using furniture components }\end{array}$ & $\begin{array}{l}\text { Using various structural } \\
\text { components } \\
\text { (floor,stairs,ramp,shaft...) }\end{array}$ & $\begin{array}{l}\text { Generating various camera views } \\
\text { Assigning materials }\end{array}$ \\
\hline ADEQgraphic surface modelling & $\begin{array}{l}\text { Using construction system } \\
\text { components (column,beam) }\end{array}$ & $\begin{array}{l}\text { Using lighting components } \\
\text { Rendering }\end{array}$ \\
\hline LESS or NONE & $\begin{array}{l}\text { Using dimensions } \\
\text { Preparing legend } \\
\text { 2D and 3D text } \\
\text { Making area calculations }\end{array}$ & $\begin{array}{l}\text { Designing construction frame } \\
\text { (steel,concrete) }\end{array}$ & $\begin{array}{l}\text { Generating sheets and placing } \\
\text { project on sheets }\end{array}$ \\
\hline
\end{tabular}

Students who were taking the course for first time could model the works of famous architects by individually practising different concepts with extra work outside of class instead of using simple form 
design solutions. Student 23 in 4th grade at graduation project level managed to model the centralized and rising form of The Cathedral of Brasilia by architect Oscar Niemeyer with additional studies (Figure 3).

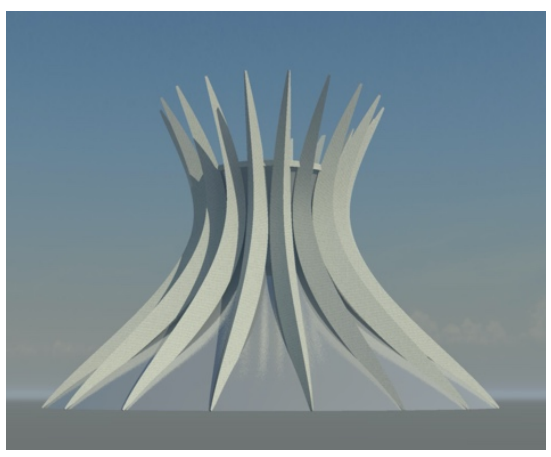

Figure 3. The Cathedral of Brasilia by Oscar Niemeyer, BIM modelling (Student 23)

According to the result obtained from the evaluation of these studies between two separate universities, product projects show level differences between universities. It is observed that these differences are at higher levels between students close to graduation. Considering the student profiles of two different universities; the students who chose courses in the first university were mainly 2 nd year students, the total student number of the second university was higher and the third and fourth year students were more in number than the second-year students, making the final products more advanced projects.

It was observed that the increase in the structural and professional knowledge of 3rd and 4th grade students selecting the course was directly reflected in final projects (e.g. Student 17, Student 18, Student 20). Especially students who were in their 4th year and started to model an additional course project, seemed to consolidate their knowledge of modelling as an extracurricular activity. As students progressed in application abilities, design additions, incorporation of constructional components, advanced plans, sections and elevations, they reached the desired technical proficiency. By processing items which make significance in the project like flooring, roof, column, beam and curtain wall, various options were made available in the interface of the software. This allows indefinite number of design options by applying the variables for each structural component. These options improve the design skill by increasing the variability of the design criteria. At the end of the research, it is reported that being able to navigate within the $3 \mathrm{D}$ project, to perceive the preview of each space as if applied on the site as an achievement that supports the project competencies.

Students who regularly repeated the course practice and made progress, further advanced the project given in the 2nd set of instructions, improved the design and reflected it on the model. These students whose skill and knowledge level increased, became able to model their Design Studio projects (e.g. Student 21, Student 22) (Table 10).

Table 10. Sample Design Studio BIM models

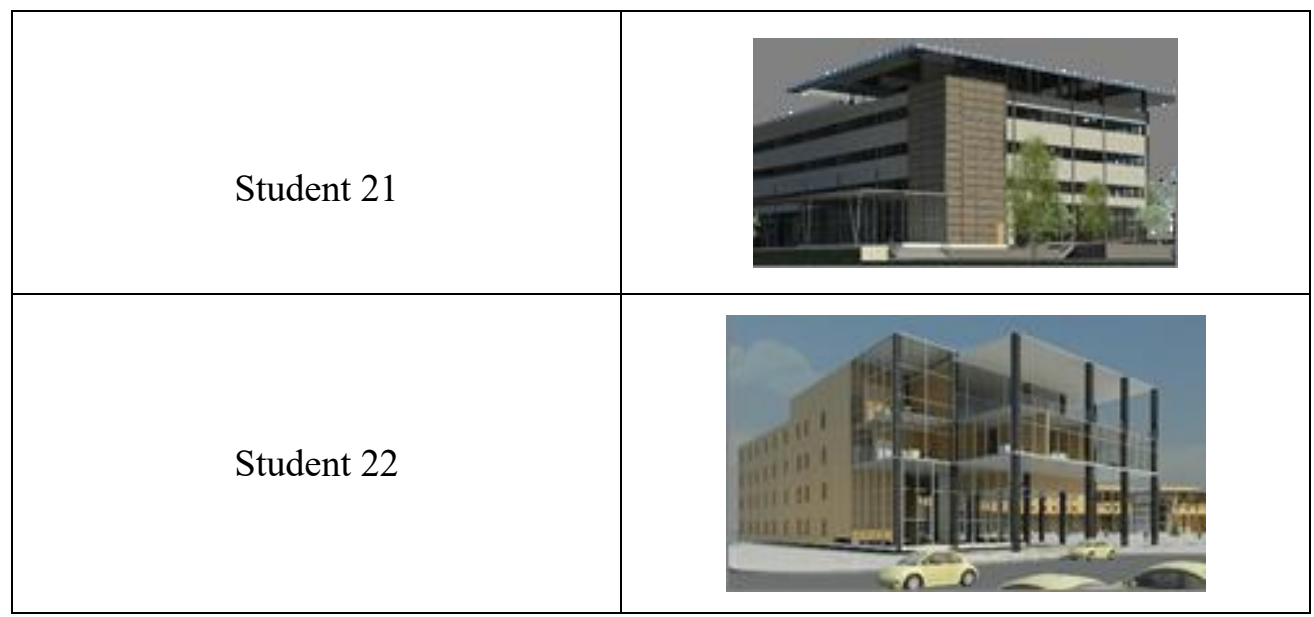

Research Article - This article was checked by iThenticate 


\section{CONCLUSION}

In this study, a course which has been designed to improve 3D modelling, structural knowledge, material knowledge and visual presentation through BIM-based software has been completed and the data acquired has been analysed. The data encompasses the project models of the course and reports of total work hours.

Evaluating the mixed group including 2nd, 3rd and 4th year students, the section with high number of 3rd and 4th year students were observed to have better levels in the final project results. The advanced parameters included in the evaluation are as follows: to be able to use all elements of constructional components, placement of interior elements and furniture, to design the garden and the landscape, to use lighting components. In addition to these, assigning material, rendering and creating legend are taken into consideration.

The study tested whether the level of an architectural project 3D model would improve or not. It was concluded that, those students who attended 3-hour-a-week in 14 weeks totally 42-hour course program fully and did extra work outside of class, made progress and were able to design a 3D model following the commands and the instructions. Extra work outside of class also enabled learners to improve in learning and applying. The amount of time spent on instructions and commands directly correlates with the progress of the model.

Those students who had never worked with a BIM-based software before were able to follow the commands at the end of the first period and at the end of the second period they were able to upgrade their performance by making design additions, defining materials, forming spaces, designing garden and landscape, installing cameras at the right angles and making the project ready for rendering. Students managed to improve their design abilities by starting with a simple plan and then making additions like roof, staircase or balcony in the given design flexibility in the second period.

When the contribution of BIM-based course effectiveness on architectural project work in Design Studios was analysed, participants who worked with different instructors modelled their projects using the '.dwg' base of their studio projects. These projects were usually of large scale like hotels, business centers or highschools. Participants made significant progress when the results of the instructions studied in the BIM interface are evaluated in terms of making flexible design additions. Material description, furniture placement, adding component details, lighting elements and the interior and exterior integrity of building design were introduced to the student as the outcomes of the course. It was conveyed to the students within the curriculum that BIM does not only mean modeling structural components such as column, beam, and floor, but has a collaborative working style in large-scale designs. Understanding and using the columnbeam structure that enables the construction of the building contributes to learning structural solutions such as the designing of the building frame and the use of reinforced concrete column-beam frame or steel structure. In addition, it has been proven in the course that environmental space, landscape, roads, various roof forms and curved surfaces can be designed through BIM. The ability of the students to visualize their design proposals and present their ideas in 3D virtual environment reflected positively on the design processes. The adoption and use of BIM in the projects were encouraged by reflecting the course outcomes on the Design Studio student projects and made BIM used in the final projects. Motivation of students towards design with BIM software in architectural education was increased. The ability of modelling projects at different levels has been acquired by the course content rather than teaching how to use a software. As a result, one of the most important outcomes of the course is to perceive and experience that a building is a whole with structural, functional, indoor and environmental components. Consideration of all structural and environmental factors played a role in the development of a successful design concept. The course outcomes have reached their goal within the scope of architectural education.

The study has revealed that modelling with BIM in architectural education contributes to the project concept development of students by providing a simultaneous plan design with a smart object based software and visualisation of 3D model. This contribution directly correlates with the students' ability to process structural components and families by BIM-based software during the design process. According to data obtained from this study, it was concluded that using BIM in architectural education contributed to design skills of students.

\section{REFERENCES}

Submit Date: 02.09.2020, Acceptance Date: 24.09.2020, DOI NO: 10.7456/11004100/009

Research Article - This article was checked by iThenticate

Copyright $(C)$ The Turkish Online Journal of Design, Art and Communication 
Abdelhameed, W. A. (2018). BIM in architecture curriculum: a case study. Architectural Science Review, 61(6), 480-491. doi: 10.1080/00038628.2018.1483888

Ahn, E., \& Kim, M. (2016). BIM Awareness and Acceptance by Architecture Students in Asia. Journal of Asian Architecture and Building Engineering, 15(3), 419-424. doi: 10.3130/jaabe.15.419

Alwan, Z., Holgate, P. \& Jones, P. (2014). Applying BIM to Sustainable Performance Evaluation in Design Projects: An Educational Approach for Architecture Programmes. In Thompson, E. M. (ed.), Fusion Proceedings of the 32nd eCAADe Conference - Volume 2, Department of Architecture and Built Environment, Faculty of Engineering and Environment, Newcastle upon Tyne, England, UK, 10-12 September 2014, pp. 437-444.

Ambrose, M. A. (2012). Agent Provocateur-BIM in the Academic Design Studio. International Journal of Architectural Computin, 10(1), 53-66.

Ambrose, M. A.,\& Fry, K. M. (2012). Re:Thinking BIM in the Design Studio - Beyond Tools... Approaching Ways of Thinking. 6th International Conference Proceedings of the Arab Society for Computer Aided Architectural Design (ASCAAD 2012), Manama, Kingdom of Bahrain, 21-23 February 2012, 71-80.

Azhar, S. (2011). Building Information Modeling (BIM): Trends, Benefits, Risks, and Challenges for the AEC Industry. Leadership and Management in Engineering, 11(3), 241-252.

Barison, M.B.,\& Santos, E.T. (2010). BIM Teaching Strategies: An Overview of the Current Approaches. Proceedings of ICCCBE 2010 International Conference on Computing in Civil and Building Engineering, Nottingham,UK, Nottingham University Press.

Becerik-Gerber, B., Gerber, D. J., \& Ku, K. (2011). The Pace of Technological Innovation in Architecture, Engineering And Construction Education: Integrating Recent Trends into The Curricula. Journal of Information Technology in Construction (ITcon), 16, 411-432.

Bonnardel, N.,\& Zenasni, F. (2010). Impact of Technology on Creativity in Design: An Enhancement? Creativity and Innovation Management, 19(2), 180-192. doi:10.1111/j.1467-8691.2010.00560.x

Çakır, H. S. (2016). The Perception of Students towards Computer Aided Design Courses in Architectural Education. ERPA International Congresses on Education, Sarajevo, June 2-4 457-463.

Çavuşoğlu, Ö. H. (2015). Building Information Modeling Tools: Opportunities for Early Stages of Architectural Design. In Y. Ikeda, C. M. Herr, D. Holzer, S. Kaijima, M. J. Kim \& M. A. Schnabel (eds.), Emerging Experience in Past, Present and Future of Digital Architecture, Proceedings of the 20th International Conference of the Association for Computer-Aided Architectural Design Research in Asia CAADRIA 2015, 427-436.

Eastman, C.M., Teicholz, P., Sacks, R., \& Liston, K. (2008). BIM Handbook A Guide to Building Information Modelling for Owners, Managers, Designers, Engineers and Contractors. New Jersey: John Wiley\&Sons, Inc.

Epstein, E. (2012). What is BIM? In Implementing Successful Building Information Modeling. Norwood, MA: Artech House, 3-10.

Farnsworth, C. B., Beveridge, S., Miller, K. R., \& Christofferson, J. P. (2015). Application, Advantages, and Methods Associated with Using BIM in Commercial Construction. International Journal of Construction Education and Research, 11(3),218-236. doi:10.1080/15578771.2013.865683

Gokuc, T.Y., \& Arditi, D. (2017). Adoption of BIM in architectural design firms. Architectural Science Review, 60 (6), 483-492. doi: 10.1080/00038628.2017.1383228

$\mathrm{Gu}, \mathrm{N}$., \& London, K. (2010). Understanding and Facilitating BIM Adoption in the AEC Industry. Automation in Construction, 19(8), 988-999.

Gurevic, U., Sacks, R., \& Shrestha, P. (2017). BIM adoption by public facility agencies: impacts on occupant value. Building Research \& Information, 45(6),610-630. doi:10.1080/09613218.2017.1289029 
Jin, R., Zou P. X., Li, B., Piroozfar, P. \& Painting, N. (2019) Comparisons of students' perceptions on BIM practice among Australia, China and UK. Engineering, Construction and Architectural Management, 26 (9), 1899-1923.

Joannides M. M., Olbina, S., \& Issa, R.A. (2012). Implementation of Building Information Modeling into Accredited Programs in Architecture and Construction Education. International Journal of Construction Education and Research, 8(2),83-100. doi: 10.1080/15578771.2011.632809

Kowaltowski, D.C.C.K., Bianchi, G., \& Teixeira de Paiva, V. (2010). Methods that may stimulate creativity and their use in architectural design education. International Journal of Technology and Design Education, 20 (4), 453-476. doi:10.1007/s10798-009-9102-z

Ku, K., \& Taiebat, M. (2011). BIM Experiences and Expectations: The Constructors' Perspective. International Journal of Construction Education and Research, 7(3), 175-197. doi: 10.1080/15578771.2010.544155

Mandhar, M., \& Mandhar, M. (2013). BIMing The Architectural Curricula - Integrating Building Information Modelling (BIM) In Architectural Education. International Journal of Architecture (IJA), $1(1), 01-20$.

Mathews, M. (2013). BIM Collaboration in Student Architectural Technologist Learning. Journal of Engineering Design and Technology, 11 (2), doi: 10.1108/JEDT-10-2011-0067

Ofluoğlu, S. (2017). BIM-based Interdisciplinary Collaborations in a Student Project Competition. CAAD Future 2017: Future Trajectories of Computation in Design, İstanbul, July 2017, 360-373.

Shing,V., Gu, N.,\& Wang, X. (2011). Atheoretical Framework of BIM-based Multi-disciplinary Collaboration Platform. Automation in Construction, 20: 134-144.

Souza, L. P. V., Ponzio, A.P., Bruscato,U. M. \& Airton, C. (2019). A-BIM: A New Challenge for Old Paradigms. In Sousa, JP, Xavier, JP \& Castro Henriques, G. (eds.), Architecture in the Age of the 4th Industrial Revolution - Proceedings of the 37th eCAADe and 23rd SIGraDi Conference - Volume 1, University of Porto, Porto, Portugal, 11-13 September 2019, 233-240.

Uzun,T. (2011). Mimarlık Eğitiminde Kullanılan Dijital Tasarım Programlarının Bellek ve Tasarım Sürecine Katkıları. Akademik Bilişim '11, 2 - 4 Şubat İnönü Üniversitesi, Malatya, 841-852.

Wu,T., \& Jeng, T. (2012). Reforming Design Studios: Experiments in integrating bim, parametric design, digital fabrication, and interactive technology. In Achten, H., Pavlicek, J., Hulin, J., Matejovska, D. (eds.), Digital Physicality - Proceedings of the 30th eCAADe Conference - Volume 1 / ISBN 978-9-4912070-2-0, Czech Technical University in Prague, Faculty of Architecture (Czech Republic) 12-14 September 2012, 49-54.

Wu, Z., Chen, C., Cai, Y., Lu, C., Wang, H.,\& Yu, T. (2019). BIM-Based Visualization Research in the Construction Industry: A Network Analysis. International Journal of Environmental Research and Public Health, 16(18),3473. doi: 10.3390/ijerph16183473.

Zarzycki, A. (2012). Component-based Design Approach Using BIM. In Achten, H., Pavlicek, J., Hulin, J., Matejovska, D. (eds.), Digital Physicality - Proceedings of the 30th eCAADe Conference - Volume $1 /$ ISBN 978-9-4912070-2-0, Czech Technical University in Prague, Faculty of Architecture (Czech Republic) 12-14 September 2012, 67-76. 